\title{
THE FUTURE OF EASTERN WHITE PINE IN CANADA ${ }^{1}$
}

\author{
BY EWAN R. CALDWELL ${ }^{2}$
}

\begin{abstract}
Chief Forest Engineer, Gillies Bros. \& Co. Ltd. Graduated with the degree of B.S.F. from the University of New Brunswick in 1948; B.A.Sc. Laval, 1954. Member of the C.I.F. and Corporation of Forest Engineers of the Province of Quebec.
\end{abstract}

The problem in considering the future of eastern white pine, or to be more specific Pinus Strobus (L.), is that of its probable future value as commercial species. Public announcements have been made by officials of the Department of Lands and Forests of the Province of Ontario that very shortly the volume of production of white pine and red pine lumber will be drastically reduced. This will not be brought about by any whim of the Department, but will occur because the supply of mature pine timber will just simply be very largely used up. It is estimated that in one forest district of the Province comprising 2,740,000 acres of productive forest land, on which the present annual cut of pine timber is about $65,000,000 \mathrm{f}$.b.m., the annual cut in about 15 years will decrease to about 12 million to 15 million f.b.m. It is believed that it will be some years, probably several decades, before the annual cut will increase. When the increase does occur, it will be because present immature stands will have become of merchantable age or size. This is only one forest district, but it is indicative to a greater or lesser degree of a trend common to the pineproducing districts of Quebec and Ontario. There will always be some pine produced but it is quite certain that the total volume of cut will be reduced.

The demand for pine lumber, pickets and box boards in Canada, the United States and abroad has been and is quite strong. When the supply diminishes what will happen? Undoubtedly other species will be used as substitutes to fill the gap. At the present time Philippine mahogany, Idaho white pine and sugar pine are competing with eastern white pine clear grades for specialty uses. Quite possibly synthetic materials such as composition boards or plastics or entirely different materials such as aluminum or other metals will be used as substitutes. If the supply of pine should after some decades once more become adequate, will it be able to re-assert itself as one of the premium timbers?

White pine has qualities that make it a most desirable species for a host of uses particularly where soft texture, dimensional stability and resistance to decay are required, and it is quite probable that it could regain most markets lost due to low supply. Unfortunately no reliable market exists for white pine for other purposes such as pulpwood. Therefore, tops, cull logs and cull trees are left in the bush. The cull trees left are frequently the only source of seed and the geneticists tell us that future stands developed from seed thrown from cull trees will probably tend to be of inferior quality. In addition white pine is

\footnotetext{
${ }^{1}$ Paper presented at the 48 th Annual Meeting of the CIF held in Chicoutimi, P.Q., October 2 to $5,1956$.

${ }^{a}$ Chief Forest Engineer, Gillies Bros. \& Co. Ltd., Braeside, Ontario.
} 
generally found in mixture with other species. In most of the areas where commercial white pine stands now exist there is no market for these other species. In order to manage the stands for pine, these other species should be controlled but it is not economically feasible to do so. It may be necessary to forget about attempting to manage for white pine and favor white or red spruce. Spruce makes good lumber, seeds more prolifically than pine, and can compete more readily with other vegetation. In addition there is a demand for spruce pulpwood. Spruce tops and sawlog culls can be used for pulp thus lowering the overhead cost of extraction or the whole stand can be cut for pulp if circumstances warrant such a step.

Many manufacturers of pine lumber have grave doubts about the advisability of investing in the future of their raw material mainly because of existing taxation and land tenure systems. On the other hand this attitude is disputed by those who believe that the future of pine will always be good-notably among these are some Department officials. These conflicting attitudes were brought to light in the White Paper of 1954 prepared by the Ontario Department of Lands and Forests and in subsequent discussions between members of the industry and the Department.

Two aspects must be considered in answering the question of future worth of white pine. The first is the purely scientific aspect or can we regenerate and grow white pine under existing pine stands and on land that formerly grew white pine.

The history of white pine and the white pine industry in Eastern Canada is fairly well known and reasonably well documented. The tales of trials and triumphs of the lumberjacks who went to the woods in the early fall and came out the following spring with the drive of sawlogs or square pine have become part of the folklore of our land and are the basis of many of the romantic thoughts that the general public entertain about life in the bush. These men by sheer bullwork performed miracles in removing immense quantities of wood. They garnered a crop ripe for harvest. It is only regrettable that observations and measurements of these so-called "virgin" pine forests were never made in quantity or quality to leave for us a picture of the ecological aspects of these forests.

From the early 1900's on, an amazing number of tables have been prepared for white and red pine: standard volume tables, height diameter curves and diameter volume curves, taper tables and tables of bark thickness, to mention a few. Many articles of generalities about white and red pine have been written. Many of these are of interest and some of real value in attempting to assess the future of white pine. Unfortunately very little basic research into why and how white pine behaves as it does has been carried out or appears in the literature and particularly that pertaining to Eastern Canada. This is lamentable but not without reason. The early researchers were hampered by lack of tools and techniques to measure and assess all the obscure factors of soil and climate or site and association which we now know have such profound effects on the occurrence, growth and reproduction of any species. 
Here is the first step in preserving the future of eastern white pine as a major commercial species. Basic fundamental research into every aspect of the functioning of the species must be accelerated or commenced and maintained. Once basic information is produced it must be assessed, tabulated and presented in such a manner that operating foresters will be able to recognize on the ground the conditions referred to in print.

Some steps have been taken in this direction. The earliest that I know of in Eastern Canada is a thesis by R. G. Hosie, now Professor at the Faculty of Forestry at the University of Toronto, in which he shows a relationship between the degree of association of minor vegetation species and the natural occurrence of pine on different sites. Currently the Dominion Forest Service is publishing a Pine Monograph the authors of which are presenting concrete and valuable information on growth and yield of pine and pine site classification using land forms recognizable in aerial photographs. The Faculty of Forestry of the University of Laval has directed student research along some promising lines such as pine site classification based on plant associations and the effect of varying concentrations of trace elements on the rate of metabolism of roots and other basic problems. The Ontario Department of Lands and Forests is carrying out research on various pine problems and the Bureau of Silviculture and Botany of the Department of Lands and Forests of Quebec has established permanent sample plots in pine stands and is interpreting data obtained therefrom. At least one pine-producing company is actively engaged in carrying out large-scale experiments on silvicultural treatment of pine stands to try to obtain pine regeneration with technical evaluation of results being carried an by the Dominion Forest Service.

These activities are of great value but they must be continued and intensified.

There is little doubt but that the technical problems of pine regeneration and culture can be solved and that practical silvicultural measures for the application of the information gained can be derived.

Most of the pine which has been harvested to date has come from overmature stands. If these stands had not been cut, they would have been lost by natural decadence or mishap. In effect the cutting of these stands has been a form of conservation. Unfortunately a combination of circumstances has led to the virtual disappearance of commercial quantities of pine from large areas on which it was at one time the principal species. Why has it disappeared from these areas? It has gone because on a large part of the area on which it occurred it was there by chance. In other areas it was due to disappear anyway because the cycle of natural succession would have removed it in due course. Things were just speeded up by the logger's axe. In many sites which might naturally have supported pine as a climax species it has disappeared because all trees in the stand were of loggable size and no source of seed was left after logging. On the better sites the jungle of undergrowth effectively chokes out almost all pine regeneration. Very often fires after or before logging have very effectively removed every vestige of advanced regeneration from the 
burnt area. The heavy seeded pine on the fringe of the burn can at best throw seed only a few hundred feet into the burn. That area is lost as a pine-producing area for generations to come.

It takes only ten white pine trees to the acre, averaging $18^{\prime \prime}$ D.B.H. and 80 feet tall, to make a merchantable stand, providing there are enough acres of this type of stand in one locality to make a cut. That means that each pine has theoretically 4356 square feet in which to grow. Actually this is never the case. A great many trees of several species compete vigorously with the ten pine trees for the balance of the acre. When these ten pines are cut, the progeny of the other species usually take over the openings left by the removal of the pine. Even if pine regeneration is present at the time of cutting, it is very frequently suppressed to extinction.

Most of these competing species are at the present time unmerchantable either due to lack of markets or the prohibitive high costs of transporting them to a point of utilization. Usually prolific seeding deciduous species are the chief offenders. The treatments which will be devised by technology to aid the natural regeneration of pine will almost certainly involve the reduction of competition. Markets must be created for these competing species or cheap and efficient methods of suppressing them must be devised. The trend towards utilizing many deciduous species for pulp as well as veneer and saw timber will greatly help the management of pine stands by gradually making it possible to carry out silvicultural cuttings at a profit or at least without too much loss. In addition hardwood cutting will extend the life of existing pine stands by making it possible to cut very scattered pine which would otherwise be too costly to harvest.

The second consideration in thinking of the future of white pine has to do with land tenure and forms of taxation.

To begin with, most of the land which produces pine commercially is held by the Crown. Sections of this land of varying sizes and varying productive capacities are licensed to individuals or companies who usually invest considerable amounts of money in plant and equipment and development to harvest the pine on the land and manufacture it into its commercially usable forms.

The method of acquiring a licence or limit may take any one of several forms but in the final analysis the person who acquires the privilege of cutting timber on Crown land always finds that he has entered into an agreement with the Crown. In this agreement the Crown invariably maintains absolute ownership and control of the land and incidentally the forest thereon. The agreement is renewable at certain stipulated intervals-often on a yearly basis, sometimes every three years, but rarely, for saw timber operators, at intervals exceeding ten years. It is conceivable that for various reasons a renewal of a license might not be forthcoming. For instance, there have been cases where licenses have been greatly reduced in extent by colonization without recompense to the license holder. It is conceivable that a change in policy of a government could bring about the refusal to renew existing licenses. Years ago when it was decided that the Crown would retain title to timber lands and the forests were 
nearly all mature and thought to be almost inexhaustible, there was perhaps some justification for the system of limit tenure being instituted. The lumberjack cleared arable land for settlement and his license guaranteed him legal right to cut timber on certain areas with access to the courts to prosecute poachers. When the land was cleared he was hailed as the settlers' benefactor and was urged to clear more land. Unfortunately this system of licensing forest land that solved the problems of a century ago is retained today. Times have changed and so have the forests and the demands made upon them. Forest land tenure methods must be brought up to date.

Now we know we are approaching the last of our original pine stands. The pine operator cannot move on to new territory. In some instances pine stands are being cut over for the fourth or fifth time and each time they have been cut over the regenerating pine area has become smaller. We are faced with the possible necessity of artificially reproducing our pine forests. It is prescribed by law in at least one Eastern Canadian Province that when timber is cut it must be shown that suitable regeneration is assured. If deemed necessary, planting must be carried out to achieve this end. Silvicultural treatment of one form or another to provide adequately for a future crop is satisfactory in lieu of planting. No matter what method is used to try to bring about the start of a future crop, expense in incurred by the operator. Most operators are interested in remaining in business and they must have raw material with which to carry on their business. If given some incentive in the form of assured land tenure for at least one complete rotation or longer as are the limit holders in British Columbia, primary pine producers or pine limit holders would be much more interested in investing in the future of growing timber.

If a farmer should rent a farm from a landowner under an agreement that had to be renewed every day and which could be cancelled at any time of renewal by the landlord, without recompense to the tenant for his unharvested crop which he had planted at his personal expense, the farmer would be thought to be mad. In effect, however, this situation exists in respect to the timber operator primarily interested in pine, or saw timber in general. His crop takes at least 100 years to mature with his lease renewable annually with nothing but a verbal statement that his lease will not be cancelled without due cause. The farmer's crop matures in one growing season.

In addition I have been told that even if an operator expends funds to regenerate the land he cuts over, and assuming that he would still be operating that same land when these trees reach maturity, he must pay the Crown stumpage when he cuts them at the same rate that applies to stands produced naturally. This will happen even though the operator has paid rent for the land producing the crop. The reason for this attitude is that if any consideration in the form of reduced charges or assistance in building improvements were given the operator for having started a crop, it would only mean increased profit to the operator and none to the Province since the Federal Government collects the income taxes.

Income Taxes or the interpretation of parts of the Income Tax Act also have their effect on the future of white pine and incidentally of other species 
by making it unattractive to hold Crown Land for the purpose of growing new crops of timber. Many limit holders have limits in different sections of the country separated by licenses belonging to others. Even if licenses are contiguous, they are frequently divided by political or natural boundaries into separate units. If a unit is being operated, carrying charges or non-operating expenses may be charged against the operation as an expense. If, however, a unit is not being operated, carrying charges may not be charged against the operations on other units but must be capitalized. This means that no relief from taxation can be obtained from spending money to hold a limit or grow trees. If an operator cut over a limit and started the next crop, once he was no honger cutting timber on this limit the cost of maintenance and inspection of his crop and maintenance of improvements, maintenance of boundaries and cost of ground rent and fire tax would all be capitalized until he started to operate that limit again. When operations recommence, the accumulated capital charge is divided into the estimated stand on the limit. The result is the amount per thousand f.b.m. which can be written off against the annual cut.

As an example, suppose a license of 100 square miles has been entirely cut over, and after cutting pine regeneration had established itself fairly well over the area. No cutting can be carried out until regeneration can reach maturity. All charges against this limit must be capitalized until it is operated again.

Assume that the annual ground rent and fire taxes amount to $\$ 20.00$ per mile which is less than the usual cost for such items in Quebec and higher than the present charge in Ontario. Using this figure the total annual charge would amount to $\$ 2,000.00$. If the total boundary amounted to 40 miles of line and 4 miles of line was freshened up every year at a cost of $\$ 50.00$ per mile ain additional annual charge of $\$ 200.00$ would occur. Annual inspection charges might be as little as $\$ 200.00$. At least 4 inventory cruises would be required in the area in 100 years and might cost about $\$ 5,000.00$ each. Thus over a hundred year period the total charges capitalized could amount to $\$ 260,000.00$. If the mature stand amounted to $500,000,000$ f.b.m., which would be a very good stand, the depletion allowed when operations commenced would be $\$ 260,000.00$ divided by 500,000 or 52 cents per thousand. Assuming an annual cut of $10,000,000$ f.b.m. the annual depletion would be $\$ 5200.00$ per year. Thus an additional 50 years would be required to bring the charges against this limit back to nothing.

One hundred and fifty years is a very long time to have any money tied up in any investment with no assurance of tenure, no interest on the investment and in addition accept the risk of fire, windthrow, insect attacks and disease.

Although these figures are hypothetical they are fairly close to actual fact. There are actual cases where pine limits have been held for as long as 50 years with the hopes that they would produce raw material in the future. On at least one area so held annual charges have increased $500 \%$ since 1900 and stumpage and royalties have increased $400 \%$.

Supposing a limit had been cut over and the operator had to plant to get regeneration. His average cost of planting might be $\$ 20.00$ per acre or 
$\$ 12,800.00$ per mile. It is quite possible that silvicultural treatment used to produce the same results as planting will cost almost as much as planting. Assuming no interest charges on this investment, the amount invested in rogeneration for 100 square miles would amount to $\$ 1,280,000.00$. Unfortunately no pine operator is very likely to step forward with $\$ 1,280,000.00$ for every 100 square miles of his limit at no interest even if he had that much money just lying around. If he expected to get a modest return of $31 / 2 \%$ on his investments, he would have to sell his product for $\$ 62.39$ per thousand more than he does now if he got an average stand of 10,000 f.b.m. per acre.

In addition the operator accepts the risk of loss from fire, windstorm, insect and disease with no compensation or reasonable insurance. Remember also that the license holder has no legal assurance of holding this land until he can harvest the crop he has invested in so heavily. This is not the kind of prospect that invites confidence in investing in the future. Certainly no bank would even consider lending money for such a scheme.

In summing up, even though the foregoing remarks may lead one to believe that I do not think much of the future of white pine, there are distinct possibilities for the future of white pine.

It is almost certain that research can show us how to go about getting pine regeneration where pine stands still exist. Research may perhaps even find out how to regenerate pine on suitable sites where pine does not now form a merchantable crop without spending immense sums to do so.

If the demand for pulp or other products from the many species that usually occur with pine continues to develop, or in short, if multiple utilization becomes a reality, then it may well become possible to manage our forests and at a reasonable cost. It might even develop that some revenue could be derived from an area while waiting for the regenerated pine to mature.

Enlightened legislatures may see fit to give the license holder some form of guarantee of tenure and thus give the incentive to take a real interest in the land and the timber crops it may support in the distant future. Taxation rulings can be changed and a fair deal given to the investor in future forests. These two factors apply to all Crown Land under license no matter what species are being grown on that land. At the present time, however, the problem is most pressing in regard to white pine due to the diminishing reserves of this species and the great length of time generally taken to produce a merchantable crop. 